\title{
Uneven compensation and relocation for displaced residents: The case of Nanjing
}

\author{
Yi Hu ${ }^{\mathrm{a}, 1}$, Pieter Hooimeijer ${ }^{\mathrm{b}, 2}$, Gideon Bolt ${ }^{\mathrm{b}}$, Dongqi Sun ${ }^{\mathrm{c},}{ }^{*}$ \\ a Urban-Rural Planning Administration Center, Ministry of Housing and Urban-Rural Development, Beijing 100835, China \\ b Department of Human Geography and Planning, Utrecht University, Utrecht 3584CS, Netherlands \\ c Institute of Geographic Sciences and Natural Resources Research, CAS, Beijing 100101, China
}

\section{A R T I C L E I N F O}

\section{Article history:}

Available online 6 February 2015

\section{Keywords:}

Displacement

Uneven compensation

Affordable housing

Purchasing discount

Nanjing

China

\begin{abstract}
A B S T R A C T
Land marketization and housing commodification have stimulated inner-city restructuring and urban expansion in China and have also induced a large amount of population displacement. Affordable housing, as part of compensation, tends to be the most common relocation housing for displaced households. It is allocated through two approaches: in-kind compensation and monetary compensation. Local government provides in-kind compensation to displaced households in the form of affordable housing, as direct compensation for demolished houses, and gives priority to those who have received monetary compensation to enable them to purchase affordable housing at a discount from the market price. The process of negotiation between local government and displaced households is complicated. As a result, uneven compensation occurs in terms of compensation approaches, as well as in how much displaced households are paid for similar new affordable houses. This study conducts a detailed analysis of the uneven displacement compensation and relocation process. It uses residential surveys conducted in Nanjing to examine uneven compensation along two dimensions: compensation approaches and the purchasing discount on new, compensated affordable housing.
\end{abstract}

๑) 2015 Elsevier Ltd. All rights reserved.

\section{Introduction}

Market-oriented reform has brought a series of socio-economic transformations, including land marketization and housing commodification, which have greatly stimulated large-scale innercity restructuring in China (Gaubatz, 1999; Wu, 2002; Zhang \& Fang, 2004). A large amount of real-estate capital is invested in inner-city areas to build commercial housing and upgrade existing buildings, and in turn, to improve both the inner city's image and its living conditions. These redevelopments are caused by increasing landbased interests or rent gaps (Dowall, 1994; Shin, 2009; Smith, 1987). Negative effects of urban redevelopment have been widely discussed in the existing literature (Hartman, 1980; Jacobs, 1961; Kempen \& Priemus, 1999). However, redevelopment starts with a large-scale demolition and displacement of old neighborhoods.

\footnotetext{
* Corresponding author. Tel.: +86 18612729027; fax: +86 1064854230.

E-mail addresses: yisarah0504@gmail.com (Y. Hu), p.hooimeijer@uu.nl (P. Hooimeijer), g.s.bolt@uu.nl (G. Bolt), aibidsk@163.com (D. Sun).

1 Tel.: +86 1057811591; fax: +86 1057811704 .

2 Tel./fax: +31302533205 .
}

A large number of original residents must relocate in the face of increasing urban land values and for real-estate profit generation. Every year in Britain, 144,000 people are forced to leave their original homes because of housing clearance and gentrification (Atkinson, 2000). In the Netherlands, 60,000 dwellings were demolished as a result of the Big Cities Policy in 1994 (Bolt \& Kempen, 2010). China is no exception to this trend, as urban redevelopment in contemporary Chinese cities is taking place on an unprecedented scale (Shin, 2009). Between 1990 and 2000, it is estimated that approximately 330 million square meters of housing across China was demolished (Li \& Song, 2009). From 2000 to 2010, the city of Shanghai demolished 60.14 million $\mathrm{m}^{2}$ of housing, leading to the displacement of more than 646,000 households (Shanghai Statistical Bureau, 2011). In Nanjing, according to Yuan, Zhu, and Ma (2010), 1.2 million $\mathrm{m}^{2}$ of housing was demolished in the inner city during the period 2004-2006. During the past decade, displacement has been a growing phenomenon that is closely associated with market-oriented land and housing transformations.

China is undergoing rapid urban expansion because there is insufficient inner-city land to meet the demands of urban development and urban population growth. A large amount of 


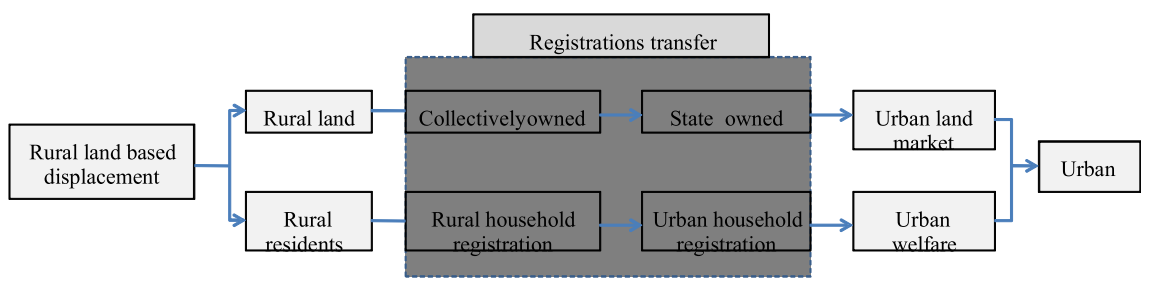

Fig. 1. Rural displacement process.

collectively owned rural land on the urban fringe has been swallowed up by the city, and this has led to many rural residents being displaced. When urban expansion requires more land, local government acquires land from the city's suburbs. According to land ownership regulations in China, this land is owned by the rural committee rather than the state. Therefore, the process of land acquisition requires several steps: relocating rural residents who live on the collectively owned land; shifting their household registration $^{3}$ ( $h u k o u$ ) from rural to urban to enable them to gain access to urban welfare (Wang \& Murie, 1999); and collectively transferring land-ownership registration to the state ${ }^{4}$ (Fig. 1).

Displacement induced by both inner-city redevelopment and urban expansion in China has prompted many scholars to conduct critical research. The existing literature has focused on the politicaleconomic reasons for displacement. Western classical theories, such as global urbanism, neo-liberalism and gentrification, are used to explain redevelopment mechanisms (Cartier, 2002; He \& Wu, 2009; Lee \& Zhu, 2006). Other literature has focused on the implementation process involved. Theories of growth coalition, growth machine and urban regime have been used to analyze China's displacement activities that are controlled by local government and developers (Yang \& Chang, 2007; Zhang T., 2002; Zhang \& Fang, 2003; Zhang \& Wu, 2008). Other studies have revealed the socio-economic implications relating to urban redevelopment (Hao, Sliuzas, \& Geertman, 2009; Leaf, 1995; Wang \& Wu, 2010; Wu, 2004).

In this process it is residents who are most affected. However, there has been little research conducted into the effects on displaced residents of urban restructuring and urban expansion. The exceptions are the studies by Wu (2004) and Li and Song (2009) on displaced residential relocation in Shanghai. Wu examined displaced relocation outcomes resulting from changes in housing tenure, built forms and housing conditions and compared them with pre-relocation. He further used descriptive statistics to evaluate the benefit level, based on per capita housing space, of people who were relocated for different reasons: infrastructure development, real-estate development, workplace housing allocation, and congestion alleviation programs. In his paper, Wu stressed that the process of displacement and relocation is a complicated process of negotiation involving residents, government agencies and demolition companies. Displaced households can bargain for compensation and relocation benefits. Therefore, it is expected that uneven relocated housing distribution exists not only between displaced households and other relocated households, but also within displaced households. This finding is confirmed in the study by $\mathrm{Li}$ and Song on the level of satisfaction with dwellings and neighborhoods of displaced residents in Shanghai. The results show that although some displaced residents complain about unfair and

\footnotetext{
${ }^{3}$ Hukou in China requires each citizen to register in one place for the status of regular residence. This system has long been used to restrict migration (Chan, 1999; $\mathrm{Wu}, 2004$ ), including migrants from rural to urban areas in the same city. Hukou registration status is associated with welfare. Only residents with local urban hukou have access to urban services such as education, jobs, housing, and healthcare.

${ }^{4}$ Collectively owned land cannot be used for commercial purposes.
}

unjust compensation and relocation, they are still more satisfied with their relocated housing conditions than stayers and migrants. In their conclusion, $\mathrm{Li}$ and Song also pointed out that displaced residents would try various tactics and strategies to negotiate for better compensation. Thus, they cannot be regarded as passive actors in residential redevelopment.

In the recent process of large-scale redevelopment and displacement relocation, it is critical to study uneven displacement compensation. Although both Wu (2004) and Li and Song (2009) recognized that uneven compensation and relocation exist among displaced residents, they did not conduct detailed analyses on the uneven compensation and relocation process, nor on which factors affect the level of disparity. Based on their work, this paper provides further analysis of the uneven compensation and relocation of displaced residents in China. Following an interpretation of the relationship between land ownership and housing, which are directly related to housing displacement and compensation policy in China, the next section introduces two levels of compensation policies, and this is followed by an explanation of how uneven compensation and relocation occur. We then present an empirical analysis of uneven compensation in two steps: how household-related factors affect compensation approaches (in-kind and monetary) and how household-related factors affect the level of monetary compensation, if households received monetary compensation.

\section{Relationship between land ownership and housing}

Land ownership is an important institutional factor that divides housing into two different systems. After the foundation of the People's Republic of China, the central government stipulated two types of land ownership in socialist China: state owned and collectively owned. All urban land is owned by the state, and rural land by rural collective committees. Administrative allocation was the only approach to urban land allocation until 1988, when, as part of the reform of the economy, the Land Administration Law was revised to allow state-owned land-use rights to be transferred to developers for commercial development, following the payment of land-use rights transfer fees. Thus, a nationwide land market was launched (Huang, 2003; Lin \& Ho, 2005).

However, collectively owned land cannot be put on the land market, and it is illegal to use it for commercial development. Collectively owned land can only shift its ownership to become state-owned land, and it is only then that the land can be leased for commercial development. But this ownership-transfer process is monopolized by government, which means that only the government can buy the collectively owned land from the collective committee.

As a result of the dual-track land-ownership system, housing built on the two different types of land has different rights in the housing market. Housing on state-owned land can be sold on the housing market and used as collateral for loans. According to the Land Administration Law, housing owners on collectively owned land are allowed to possess, use, and benefit from the ownership of the housing and land (Lin \& Ho, 2005). However, the owner has no 


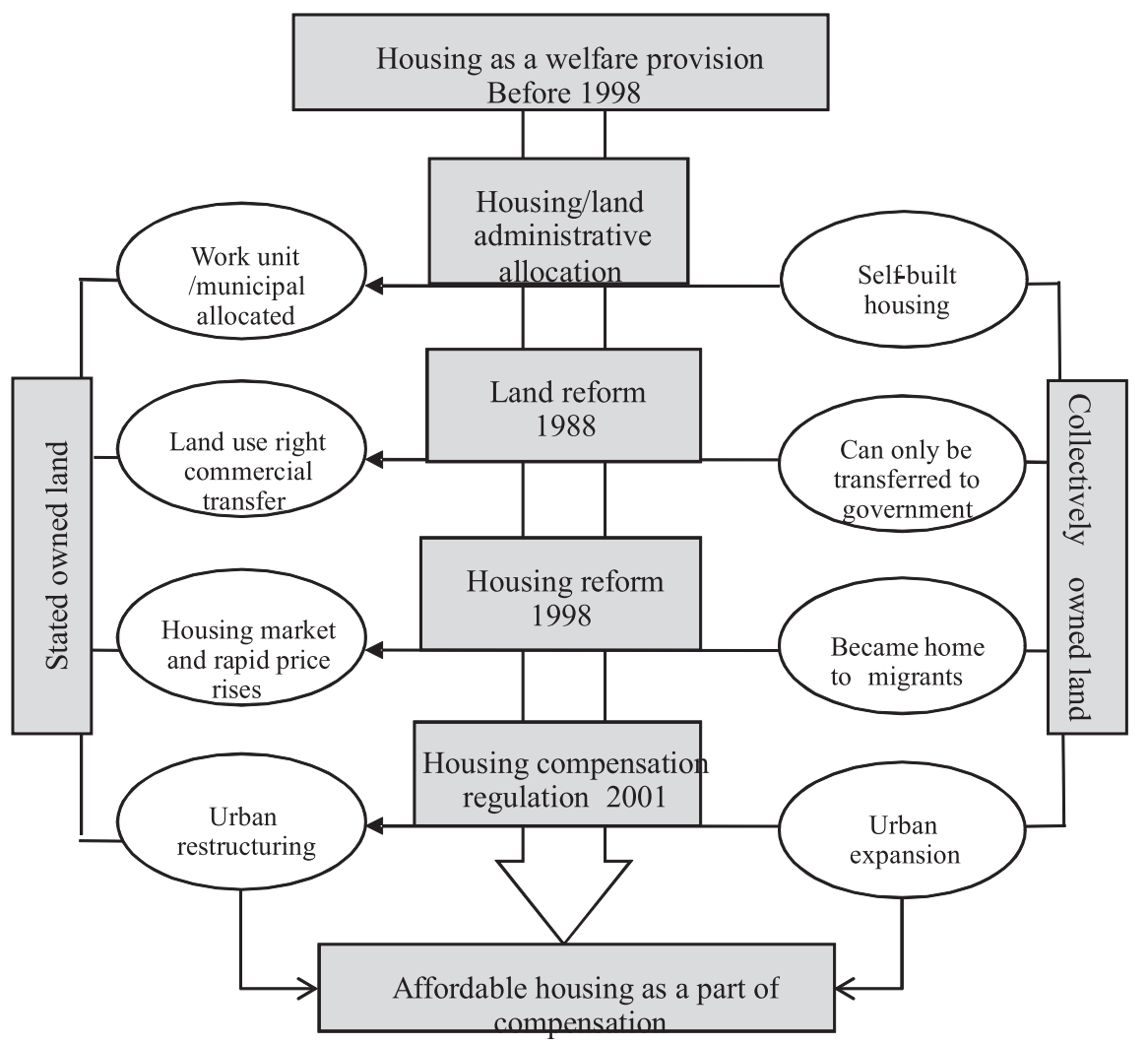

Fig. 2. Progress of housing development with changes in national policies in China.

right to sell off the house or land on the housing or land market. Because of these different types of land ownership, separate policies have often been developed for urban and rural areas (Wang \& Murie, 2000), including policies on compensation and relocation for housing displacement.

\section{National and municipal displacement compensation policies}

National displacement compensation policies based on different types of land ownership

Most displacements in Chinese cities occur in owner-occupied housing. As a result of the rent reform in 1988, a large amount of public rental housing shifted into private ownership. The percentage of urban public housing decreased from $75 \%$ in 1980 s to $16.3 \%$ in 2000 (Huang, 2004; Logan, Fang, \& Zhang, 2010). Owneroccupied housing dominates in urban areas, and in rural areas, the proportion of private housing is even higher. Almost all rural residents live in self-built owner-occupied housing. Therefore, allocating another owner-occupied affordable dwelling tends to be the most common approach in relation to displaced households (Fig. 2).

Before the market-oriented housing reform in 1998, there was no nationwide housing market in China, except in some experimental housing-market areas. Housing could not be bought and sold; rather, it was distributed from the top down. The state, local government and work units were in charge of housing construction, and then allocated the dwellings to urban residents or workunit employees (Logan et al., 2010; Wang, 2000). Thus, in the case of project-induced displacement, all displaced households would be allocated another dwelling by the local government or work unit, to live in either permanently or temporarily until they could return to the original area.
The situation changed following the housing reform in 1998. In order to promote the market-oriented housing reform, the compensation policy for urban housing demolition changed with the "Regulation on the Dismantlement of Urban Houses"5 (Order of the State Council No. 305), which took effect in 2001. For the first time, monetary compensation could be used in the case of housing demolition on state-owned land. That meant that displaced urban residents were now able to choose their new dwelling on the housing market using their monetary compensation. There were two important points:

1) Compensation for displacement could be in the form of property exchange (chanquan zhihuan, in-kind compensation), as well as monetary compensation.

2) The value of monetary compensation would be determined on the basis of the displaced housing location, the housing purpose, and the construction area.

This policy basically set out two approaches to relocation compensation: in-kind and monetary. Although it was replaced by the new rule "Regulation on the Expropriation of Buildings on State-owned Land and Compensation" (Order of the State Council No. 590) from 19th January 2011, these two compensation approaches were retained in the new regulation on state-owned land in relation to housing demolition.

However, housing marketization only existed for housing on state-owned land and did not apply to housing on collectively owned land in rural areas. According to the Land Administration Law, the government needs to compensate rural residents when acquiring their land. However, there is no regulation at national

\footnotetext{
5 http://www.lawinfochina.com/display.aspx?lib=law\&id=4872.
} 
Table 1

Property exchange compensation guide for per capita space in housing on collectively owned land in Nanjing.

\begin{tabular}{|c|c|c|c|c|}
\hline & Standard 1 & Standard 2 & Standard 3 & Standard 4 \\
\hline Previous housing size & $<28 \mathrm{~m}^{2} /$ person & $28-42 \mathrm{~m}^{2} /$ person & $42-56 \mathrm{~m}^{2} /$ person & $>56 \mathrm{~m}^{2} /$ person \\
\hline New affordable housing size & $19 \mathrm{~m}^{2} /$ person & $21 \mathrm{~m}^{2} /$ person & $25 \mathrm{~m}^{2} /$ person & $28 \mathrm{~m}^{2} /$ person \\
\hline
\end{tabular}

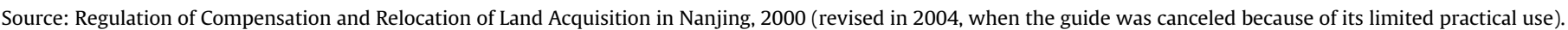

level on compensation for the demolition of housing on collectively owned land.

If housing on collectively owned land is demolished, the village collective committee usually compensates displaced households through negotiation, and provides another plot of land (zhaijidi) within the village for them to build a new house. However, if the whole village is demolished and no more collectively owned land remains, rural residents must relocate to urban areas ${ }^{6}$. Individual households will receive compensation for their housing, housing plot, farmland, and lost (unharvested) crops on farmland. In addition, compensation for the other public areas on collectively owned lands, such as public facilities and roads, will be given to the collective committee.

Given that collectively owned land has no market price and can only be transferred to the state, the compensation price for the land that is controlled by local government is very low. The biggest share of the compensation for rural residents comes from their house. As there are no national-level compensation policies governing housing built on collectively owned land, it is not uncommon for rural residents' housing to be compensated in accordance with the standards of housing on state-owned land.

\section{Municipal displacement compensation policies based on different} types of land ownership: the case of Nanjing

In Nanjing, displaced households who are given in-kind compensation can receive affordable housing as a direct compensation for the demolished house. Those who are given monetary compensation have priority to purchase affordable housing at a favorable price much lower than the market price. Given that the monetary compensation they receive is rather low ${ }^{7}$ compared to what they would need in order to purchase commercial housing, the municipal government often provides affordable housing at a discounted price as indirect compensation.

Affordable housing in Nanjing is allocated to both displaced households and low- and middle-income households. It is estimated that $75 \%{ }^{8}$ of affordable housing is allocated to displaced households (Guo, Li, \& Wang, 2011) and only 5\% to low- and middleincome households (Nanjing Planning Bureau, 2007-2020). In 2010, 4535 households were allocated affordable houses, of which 4360 were displaced households. Of these displaced households, only 12 were displaced from state-owned land, while the others were displaced from collectively owned land ${ }^{9}$.

Unsurprisingly, different housing compensation and relocation policies have been developed in Nanjing for state-owned and collectively owned land. In-kind compensation for housing on state-owned land is based on its assessed price by a housing assessment agency. The value of the new affordable housing allocated should be the same as that of the household's previous

\footnotetext{
${ }^{6}$ This is because they cannot register their hukou at other villages. Therefore, they have no right to receive a housing plot from another collective committee.

7 Monetary compensation is calculated only on building material costs and land location, not on market value.

${ }^{8}$ Source of data: http://news.nanjing.soufun.com/2012-06-03/7805798.htm.

9 There are no official statistics, but information is available from news sources: http://blog.sina.com.cn/s/blog_70b53a860100qumz.html.
}

dwelling (Management Regulation of Demolition of Urban Housing in Nanjing in 2001, revised in 2004). For houses on collectively owned land, the size of the new dwelling is based on the total space of the demolished house and the number of family members whose household registration (hukou) was registered at the address of the demolished dwelling. However, there is a maximum limit for space allocation (Table 1 ).

The process of monetary compensation based on different types of land ownership is the same. It requires a housing assessment agency, which is chosen jointly by the displaced households and the local government, to assess the value of the demolished house. The local government then sets the price on a per-square-meter basis for the relocated affordable dwelling. Finally, the price gap between the old and new houses will determine whether the displaced household needs to pay the difference, or whether the municipality will reimburse the displaced household for the difference. If the monetary compensation is less than the price of affordable housing, the household must pay the difference in price to the government But if the monetary compensation is more than the price of affordable housing, the government must pay the household.

\section{Uneven compensation and relocation: factors and processes}

The location and size of the relocated affordable housing do not necessarily reflect the housing choice or preference of displaced households, but are the result of municipal government arrangements and displacement policies. In this sense, in national and municipal policies, compensation is awarded according to the conditions of the pre-displacement situation. However, compensation and relocation are complex processes that are affected by pre-displacement conditions, negotiation capability, and a number of factors inherited from socialist institutions, such as land ownership and hukou status ${ }^{10}$. Different compensation procedures can be used for different displaced residents, and negotiations can also allow for further fluctuations in the compensation agreed. Therefore, it is not surprising that there is variation in the amounts paid by displaced households for similar relocated affordable housing, and in how much space they are given.

District governments are in charge of implementing the compensation. They negotiate with the displaced households one by one. Negotiation capability and practical factors such as the household's income can affect the outcome. This presents greater opportunities for bargaining with households. For example, according to the standard (Table 1 ), if a displaced household has only one member in a $220 \mathrm{~m}^{2}$ house on collectively owned land in Nanjing, this person will be allocated a $28 \mathrm{~m}^{2}$ apartment as compensation. But if the individual is able to negotiate with the local government, he or she may be able to obtain an apartment of $100 \mathrm{~m}^{2}$.

Another example in relation to monetary compensation is a household with 4 persons living in a $40 \mathrm{~m}^{2}$ dwelling. According to the assessment of their house, the price would be set at 8000 yuan/

\footnotetext{
${ }^{10}$ In Nanjing, it is only possible to allocate affordable housing to residents with local urban household registration (hukou). Therefore, the local government will help displaced residents with rural hukou to change their hukou in order to qualify for affordable housing and access urban welfare.
} 


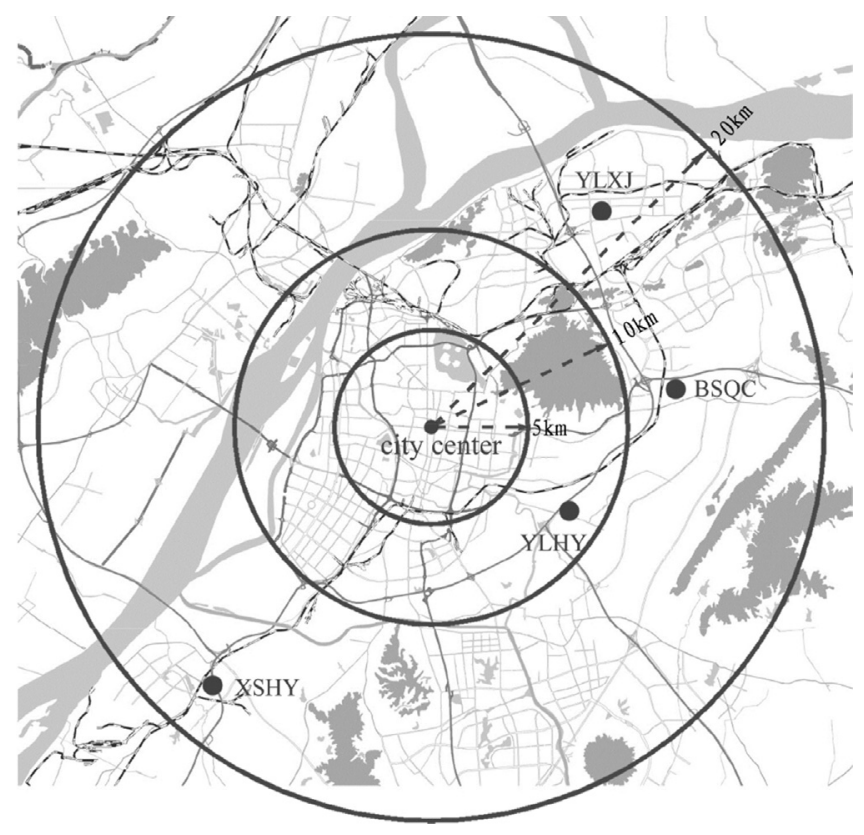

Fig. 3. Distribution of the four affordable housing areas in Nanjing.

$\mathrm{m}^{2}$. So the monetary compensation would be 320,000 yuan. The household could then purchase $76 \mathrm{~m}^{2}$ of affordable housing at 5000 yuan $/ \mathrm{m}^{2}$ (the market price is 6000 yuan $/ \mathrm{m}^{2}$ ), for a total of 380,000 yuan for the relocated affordable housing. The cash compensation would not be enough to purchase the affordable housing. In this case, negotiation would allow for different options. In the case of a low-income household, local government would consider providing a higher discount rate. However, if the displaced household negotiates for more monetary compensation, or is not classed as a low-income household and negotiates for more space in the new affordable housing, local government would not provide a higher discount on the purchase price. Therefore, to some extent the negotiation process seems to be a balance of many factors. Even households with similar pre-displacement situations coming from the same area could receive different amounts of affordable housing space and purchasing discount in the same new area.

\section{Survey data and method}

\section{Fieldwork and method}

Fieldwork was undertaken from March to August 2011 in affordable housing areas in Nanjing. A questionnaire-based survey was carried out with displaced residents relocated in four typical affordable housing areas: Yinlonghuayuan (YLHY), Baishuiqiancheng (BSQC), Yaolinxianju (YLXJ) and Xishanhuayuan (XSHY) (Fig. 3). YLHY is the largest affordable housing area in inner-city Nanjing; BSQC is the largest affordable housing area in Nanjing's municipality; YLXJ

Table 2

Information on the four affordable housing areas.

\begin{tabular}{llllll}
\hline Name & Land area & $\begin{array}{l}\text { Housing } \\
\text { stock }\end{array}$ & $\begin{array}{l}\text { First resettled } \\
\text { year }\end{array}$ & $\begin{array}{l}\text { Current market } \\
\text { price }\end{array}$ & $\begin{array}{l}\text { Distance to } \\
\text { city center }\end{array}$ \\
\hline YLHY & $0.49 \mathrm{~km}^{2}$ & 5898 & 2002 & $11,800 \mathrm{yuan} / \mathrm{m}^{2}$ & $8 \mathrm{~km}$ \\
BSQC & $1.24 \mathrm{~km}^{2}$ & 13,253 & 2004 & $9400 \mathrm{yuan} / \mathrm{m}^{2}$ & $12 \mathrm{~km}$ \\
YLXJ & $0.47 \mathrm{~km}^{2}$ & 6700 & 2003 & $8900 \mathrm{yuan} / \mathrm{m}^{2}$ & $14 \mathrm{~km}$ \\
XSHY & $0.60 \mathrm{~km}^{2}$ & $>6000$ & 2007 & 6500 yuan $/ \mathrm{m}^{2}$ & $17 \mathrm{~km}$ \\
\hline
\end{tabular}

Source: Nanjing Planning Bureau, 2007-2020 and own surveys. Source of market price: http://nj.fangjia.com/xiaoqu/ (accessed 18th December 2011). was one of the first affordable housing areas completed in Nanjing; and XSHY is on the urban fringe of Nanjing city. Information on the four affordable housing areas is shown in Table 2.

Each affordable housing area covers more than $470,000 \mathrm{~m}^{2}$. In each of the areas, 100 questionnaires were distributed. Each area was divided into several neighborhoods and questionnaires were distributed in proportion to the total number of buildings in each neighborhood.

Initially, we intended to distribute the survey door to door; however, this proved to be difficult as residents did not feel safe with strangers ${ }^{11}$. In addition, displacement and compensation are very sensitive issues. Many residents were reluctant to answer questions on these topics in their homes. Therefore, most surveys were answered face to face by residents chosen at random in public spaces and on the major roads of every neighborhood. The questionnaire targeted owners or their spouses from relocated affordable dwellings with a Nanjing local hukou (urban or rural) before displacement. In total, 349 valid questionnaires were collected $^{12}$ : 94 in YLHY, 95 in BSQC, 85 in YLXJ, and 75 in XSHY.

Two groups of displaced households were identified: those receiving affordable housing through a property exchange, and those purchasing affordable housing with monetary compensation. Since not all the displaced households received monetary compensation, uneven compensation and relocation is measured by the discount rate of purchase price per square meter. A higher discount is considered beneficial.

Under this measurement, displaced residents obtaining housing through a property exchange are considered to have received $100 \%$ discount. The answers of these residents to the question "How much did you pay per square meter for your relocated affordable housing?" in the survey were: "I received a property exchange," "I paid nothing," or "They [the government] gave me an affordable dwelling as direct compensation for the demolition of my previous house." Those who purchased their affordable housing with monetary compensation at a discounted price were considered to have received less than $100 \%$ discount. They gave an answer of the price per square meter that they paid.

The displaced households bought their affordable housing in different years. Therefore, we needed to estimate the standard market price by affordable housing area by year. To calculate the discount for each household, we hypothesized that housing-price inflation in each affordable housing area was constant. We estimated the standard market price by affordable housing area by year according to the corresponding average housing prices in Nanjing. The estimated standard market prices of the four affordable housing areas are shown in Table 3. The estimated discount for each displaced households is:

Discount $=\left|I_{a b}-J_{a b}\right| / J_{a b}$

where $I$ is the price paid by the householder per square meter; $J$ is the estimated standard market price; $a$ is the affordable housing area; and $b$ is the year of purchase.

\footnotetext{
11 Residents living in affordable housing areas complained about the unsafe environment: a lot of migrants move around or rent some of the affordable housing to live in, and no one manages this. Thus, a lot of stealing and robbery takes place. 12 We received 374 valid surveys; however, 25 of them were found to have some invalid answers. In response to the question on the source of the current housing, 5 respondents said they had inherited the relocated housing from their parents or grandparents. Although they are the owners, they do not represent the prerelocation household situation. Four respondents held hukou outside Nanjing; 16 so-called owners completed the questionnaire, but in answer to the final question, "How many dwellings do you have in Nanjing?", they said they had no dwellings. We excluded all these invalid cases.
} 
Table 3

The calculated standard market price of the four affordable housing areas 1999-2011 (yuan $/ \mathrm{m}^{2}$ ).

\begin{tabular}{|c|c|c|c|c|c|c|c|c|c|c|c|c|c|}
\hline Year & 1999 & 2000 & 2001 & 2002 & 2003 & 2004 & 2005 & 2006 & 2007 & 2008 & 2009 & 2010 & 2011 \\
\hline Average price & 2346 & 2795 & 2907 & 2939 & 3148 & 3516 & 4072 & 4477 & 5304 & 6153 & 7185 & 10,154 & 11,200 \\
\hline YLXJ & 1869 & 2225 & 2314 & 2332 & 2501 & 2795 & 3240 & 3560 & 4219 & 4895 & 5696 & 8099 & 8900 \\
\hline BSQC & 1974 & 2350 & 2444 & 2463 & 2641 & 2952 & 3422 & 3760 & 4456 & 5170 & 6016 & 8554 & 9400 \\
\hline YLHY & 2478 & 2950 & 3068 & 3092 & 3316 & 3705 & 4295 & 4720 & 5593 & 6490 & 7552 & 10,738 & 11,800 \\
\hline XSHY & 1365 & 1625 & 1690 & 1703 & 1827 & 2041 & 2366 & 2600 & 3081 & 3575 & 4160 & 5915 & 6500 \\
\hline
\end{tabular}

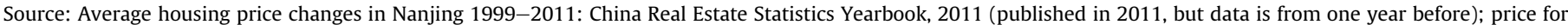
2011: Nanjing Statistics Bureau online http://www.njtj.gov.cn/.

\section{Variables}

The independent variable of household characteristics before displacement takes into account the backgrounds of not only the respondents but also their spouses. This refers to education, profession and employment. If the respondent has no partner, the variable for household characteristics before displacement is taken as the answer for the respondent. Household education can be classified as high or low level. There are four options for household profession: farmer, work-unit employee, private/foreign company, or no profession. To decide the outcome for this variable, if the respondent is a farmer, then the profession is taken as farmer. If the partner has no profession, then the respondent's profession is used. If both the respondent and their partner have the same profession, or if they have different professions and neither of them is a farmer, the profession is taken as the one corresponding to the husband. This variable also takes into account employment status following displacement. As there is data available only on employment status after displacement, but not on employment status before displacement, the current employment status is used. This is relevant, since it might affect the total price the household would have to pay for the new house and the amount of the discount applicable. If members of the household are employed following displacement, this could mean their jobs are more stable. Hence, the total price paid for the house could be higher and the discount much lower, as they are better off than those who are unemployed. Descriptive characteristics of variables used in models are shown in Table 4.

An independent variable, land ownership and hukou before displacement, was calculated. As there was a high correlation between these two, we combined them as one variable. As a result, there are four possible cases. In addition, since state-owned and rural only has four cases, we combined state-owned and rural/urban as one dummy.

Which residents are most likely to receive in-kind or monetary compensation? What factors affected the discount rate? In order to investigate these questions, a binary logistic model was used to test the uneven allocation approaches (Section: Uneven compensation approaches: in-kind and monetary), and a multivariate regression conducted to find out the relative roles of different factors when purchasing affordable housing at a discount is analyzed (Section: Uneven purchasing discount: factors shaping monetary compensation). We ran the model with average household income and age, but since these results were not significant, they were excluded.

\section{Uneven compensation approaches: in-kind and monetary}

The binary logistic model was used to find out who is more likely to obtain in-kind compensation (100\% discount) versus monetary compensation. The dependent variables for the binary logistic model are the discount rate of $100 \%$ and not $100 \%$. Only two independent variables are significant: collectively owned land and urban hukou, and no profession (full-time husband/wife). Table 5 shows the results of the binary logistic regression.

Residents from collectively owned land holding an urban hukou (CU) are more likely than other groups to receive in-kind compensation. From the survey used for this analysis (Table 6), $\mathrm{CU}$ residents mostly come from the inner city and are relocated in YLHY, which is also located in the inner city. Although residents from state-owned land (SR/U) and CU residents have similar

Table 4

Descriptive characteristic of variables used in models $(\mathrm{N}=349)$.

\begin{tabular}{|c|c|c|c|}
\hline Variables & Items & Percentage & $\mathrm{N}$ \\
\hline \multirow[t]{2}{*}{ Discount } & $100 \%$ (property exchange) & 19.2 & 67 \\
\hline & $<100 \%$ (monetary compensation) & 80.8 & 282 \\
\hline \multirow{4}{*}{$\begin{array}{l}\text { Land ownership and hukou type before } \\
\text { displacement }\end{array}$} & Collectively owned and rural & 81.1 & 283 \\
\hline & Collectively owned and urban & 10.0 & 35 \\
\hline & State owned and rural & 1.1 & 4 \\
\hline & State owned and urban & 7.7 & 27 \\
\hline \multirow[t]{3}{*}{ Household size before displacement } & Small ( $1-3$ persons $)$ & 47.6 & 166 \\
\hline & Medium (4-6 persons) & 45.0 & 157 \\
\hline & Large(7-10 persons) & 7.4 & 26 \\
\hline Average house size before displacement & & $188 \mathrm{~m}^{2}$ & - \\
\hline \multirow[t]{2}{*}{ Household education } & Low (below high school) & 49.6 & 173 \\
\hline & High (high school and above) & 50.4 & 176 \\
\hline \multirow[t]{8}{*}{ Household profession before displacement } & Farmer/self-employed & 55.7 & 194 \\
\hline & $\begin{array}{l}\text { Work unit (government agency/state } \\
\text { enterprises) }\end{array}$ & & \\
\hline & Employed after displacement & 8.3 & 29 \\
\hline & Unemployed after displacement & 12.0 & 42 \\
\hline & Private/foreign company & & \\
\hline & Employed after displacement & 8.0 & 28 \\
\hline & Unemployed after displacement & 5.4 & 19 \\
\hline & Other (full-time husband/wife) & 10.6 & 37 \\
\hline
\end{tabular}


Table 5

Binary logistic regression on two types discount ( $y=1$ if $100 \%$ discount, $y=0$ if not $100 \%$ ).

\begin{tabular}{|c|c|c|c|}
\hline & Coefficients (B) & S.E. & $\operatorname{Exp}(B)$ \\
\hline (Constant) & $-1.793^{* * *}$ & .380 & .167 \\
\hline \multicolumn{4}{|c|}{ Land ownership and hukou type before displacement (Reference: collectively owned and rural) } \\
\hline Collectively owned and urban & $1.196^{* * *}$ & .408 & 3.305 \\
\hline State owned and rural/urban & -.227 & .538 & .797 \\
\hline House size before displacement & -.000 & .001 & 1.000 \\
\hline \multicolumn{4}{|c|}{ Household size before displacement (Reference: $1-3$ persons) } \\
\hline Medium ( $4-6$ persons) & -.354 & .318 & .702 \\
\hline Large (7-10 persons) & -.020 & .560 & .981 \\
\hline \multicolumn{4}{|c|}{ Household education (Reference: low: below high school) } \\
\hline High (high school and above) & .321 & .302 & 1.379 \\
\hline \multicolumn{4}{|c|}{ Household profession before displacement (Reference: farmer/self-employed) } \\
\hline \multicolumn{4}{|c|}{ Work unit (government agency/state enterprises) } \\
\hline Employed after displacement & -.646 & .660 & .524 \\
\hline Unemployed after displacement & .488 & .431 & 1.629 \\
\hline \multicolumn{4}{|l|}{ Private/foreign company } \\
\hline Employed after displacement & .207 & .523 & 1.230 \\
\hline Unemployed after displacement & -.652 & .791 & .521 \\
\hline No profession (full-time husband/wife) & $.790^{*}$ & .452 & 2.203 \\
\hline $\mathrm{R}^{2}$ & .110 & & \\
\hline $\mathrm{N}$ & 349 & & \\
\hline
\end{tabular}

${ }^{*} \mathrm{p}<0.1 ;{ }^{* *} \mathrm{p}<0.05 ;{ }^{* * *} \mathrm{p}<0.01 ;$ S.E. $=$ Standard Error.

percentages in terms of their pre- and post-relocation, state-owned land has an insignificant effect. In contrast, collectively owned land in the inner city is the key difference for the in-kind compensation approach: such areas are China's so-called urban villages.

$\mathrm{CU}$ residents are more likely to receive in-kind compensation because they have relatively large homes, as they are the landlords in urban villages. With the rapid urban development, local government acquired land from local villages for urban expansion. However, acquiring agricultural land is much easier and costs less than acquiring housing land. Therefore, a large number of urban buildings and infrastructure were built on agricultural land, leaving housing land untouched. Since every rural household has a housing plot, such households were able to expand their dwellings themselves and benefit from the legal ownership of housing and land. In order to rent more rooms to migrants, they added floors and increased the number of rooms. Since rural-to-urban migration became a main force in China's urbanization (Hao et al., 2009; Zhang \& Fang, 2003), and high housing prices and increasing rental prices led migrants to resort to low-rent rooms, these villages have turned into residential areas for migrants, and are the so-called urban villages (chengzhongcun). The urban villages located in the inner city are especially popular with migrants because of their

Table 6

Pre- and post-location with different types of hukou and land ownership ${ }^{\mathrm{a}}$ (number of households)

\begin{tabular}{|c|c|c|c|c|c|c|c|}
\hline & \multicolumn{2}{|c|}{$\begin{array}{l}\text { Previous housing } \\
\text { location }\end{array}$} & \multicolumn{4}{|c|}{$\begin{array}{l}\text { Current affordable housing } \\
\text { area }\end{array}$} & \multirow[t]{2}{*}{ Total } \\
\hline & Inner city & Suburb & BSQC & XSHY & $\begin{array}{l}\text { YLHY } \\
\text { (inner) }\end{array}$ & YLXJ & \\
\hline $\begin{array}{l}\text { Collectively owned } \\
\text { and urban }\end{array}$ & 30 & 5 & 10 & 2 & 22 & 1 & 35 \\
\hline $\begin{array}{l}\text { Collectively owned } \\
\text { and rural }\end{array}$ & 64 & 219 & 75 & 71 & 55 & 82 & 283 \\
\hline $\begin{array}{l}\text { State owned and } \\
\text { rural/urban }\end{array}$ & 25 & 6 & 10 & 2 & 17 & 2 & 31 \\
\hline
\end{tabular}

a Our survey has a question: "Which district was your previous house located before displacement?" Districts in inner city: Baixia, Qinhuai, Gulou, Xuanwu, Xiaguan, Jianye. Districts in suburbs: Qixia, Yuhua, Jiangning, Pukou, Luhe. Part of the Jianye District is outside the first ring road (inner-city boundary), but since it has convenient transport links to the city centre (two metro lines), we treat it as part of the inner city. Part of the Yuhua District is inside the first ring road, but we treat it as a suburb. Source: own surveys. convenience for commuting to the city center and because of their low rents. Local villagers in such inner-city urban villages gain more economic benefits through renting their houses to migrants. Firstly when these urban village homes are demolished, the government of Nanjing prefers to provide in-kind compensation for $\mathrm{CU}$ residents. Given the large size of urban village houses and lots, the monetary compensation would be a substantial sum for the local government. Secondly, the in-kind compensation has a maximum of $28 \mathrm{~m}^{2}$ /person (see Table 1 ), which means that even if the displaced house is large, the household will not receive a new home of the same size as the previous one. Thirdly, the cost of affordable housing for displaced households is financed not only by local governments and districts, but also by provincial and central governments. Affordable housing primarily aims to solve the housing difficulties of low- and middle-income households, but in Nanjing it has mainly become compensation for displaced households. All these factors mean that in-kind compensation, although significant owing to the large size of the houses, still allows the district government to complete the demolition process with the lowest possible financial expenditure. As the compensation price is much lower than the market one, some displaced households who received monetary compensation cannot afford a house of the same size in the same location; they must then buy the affordable housing provided by the local government. This is especially the case for low-income families.

Households in which both the husband and wife have no profession are more likely to receive in-kind compensation: the proportion is more than $50 \%$ in the group from collectively owned land in the inner city (see Table 7). This is most likely to refer to landlords in urban villages (Wang \& Wu, 2010).

\section{Uneven purchasing discount: factors shaping monetary compensation}

What factors shape the purchasing of affordable housing at a discount rate when there is monetary compensation? A multivariate regression was conducted to find out the relative roles of the different factors shaping this compensation approach. The 
Table 7

Location and land ownership before displacement for different household professions (number of households).

\begin{tabular}{|c|c|c|c|c|c|}
\hline & \multicolumn{2}{|c|}{$\begin{array}{l}\text { Previous housing } \\
\text { location }\end{array}$} & \multicolumn{2}{|c|}{$\begin{array}{l}\text { Previous land } \\
\text { ownership }\end{array}$} & \multirow[t]{2}{*}{ Total } \\
\hline & Inner city & Suburb & $\begin{array}{l}\text { Collectively } \\
\text { owned }\end{array}$ & $\begin{array}{l}\text { State } \\
\text { owned }\end{array}$ & \\
\hline Farmer/self-employed & 50 & 144 & 177 & 17 & 194 \\
\hline Work unit & 31 & 40 & 61 & 10 & 71 \\
\hline Private/foreign company & 18 & 29 & 46 & 1 & 47 \\
\hline No profession & 20 & 17 & 34 & 3 & 37 \\
\hline
\end{tabular}

Source: own surveys.

dependent variable is the purchasing discount rate per square meter for those who received monetary compensation.

Displacement involves a negotiation process between the residents being displaced and the district governments ${ }^{13}$. Many factors play a role, and, as shown in Table 8, three of these factors are significant: CU, high education level, and work-unit employees who are employed after displacement.

In terms of coefficients, results indicate that $\mathrm{CU}$ has a higher coefficient of 24.72 for the discount rate. As explained in Section: Uneven compensation approaches: in-kind and monetary, CU residents who are landlords in urban villages in the inner city of Nanjing are those who are most affected in economic terms. Before displacement, they benefited by renting rooms to migrants, and for many this was their main source of income. However, although they were allocated another house to live in following displacement, the new conditions usually do not allow them to rent out the same number of rooms, and the location is no longer as convenient. These residents experience the greatest economic loss as a result of the displacement. Therefore, the local government has to provide better compensation conditions and higher discount rates in order for them to agree to be displaced.

Level of education is a very important factor in housing distribution, according to China's housing research (Wu, 2004). Without exception, our research found that education level had a significant positive relationship with purchasing discount with coefficient 5.095, which is consistent with the results in other Chinese housing studies on distribution, housing accessibility and housing benefits (Huang, 2003; Logan, Bian, \& Bian, 1999; Logan et al., 2010; Wu, 2004). Displaced residents with higher levels of education have a strong capacity for bargaining for a higher discount rate.

Interestingly, in this survey, residents who have a job at a work unit after displacement receive a smaller discount rate. This is at odds with many of the results reported in Chinese housing studies based on the socialist or transitional housing allocation system, where work units had positive effects on housing allocation (Huang, 2003; Logan et al., 1999, 2010; Wang \& Murie, 2000). Those studies found that those at higher levels in work units in particular could obtain more benefits (Huang, 2003).

The results of this analysis could have several explanations. One is that residents who held a position in a work unit are usually better off than farmers (Bian \& Logan, 1996; Yao \& Zhu, 1998). Hence, they are able to accept a lower discount than farmers, and may even purchase market housing.

Another explanation is that residents with a job at a work unit have a weaker position in the displacement negotiation. On the

\footnotetext{
13 Sometimes displaced households negotiate with temporary demolition companies, which are organized by district governments. Once the area is demolished, these demolition companies are dismissed.
}

Table 8

Multivariate regression on the ratio of discount, represented by the actual price paid in the group, with monetary compensation.

\begin{tabular}{|c|c|c|}
\hline & Coefficients (B) & S.E. \\
\hline (Constant) & $49.063 * * *$ & 2.294 \\
\hline \multicolumn{3}{|c|}{$\begin{array}{l}\text { Land ownership \& hukou type before displacement (Reference: collectively } \\
\text { owned and rural) }\end{array}$} \\
\hline Collectively owned and urban & $24.833^{* * *}$ & 3.625 \\
\hline State owned and rural/urban & -.058 & 3.133 \\
\hline House size before displacement & -.008 & .009 \\
\hline \multicolumn{3}{|c|}{ Household size before displacement (Reference: $1-3$ persons) } \\
\hline Medium (4-6 persons) & 2.131 & 1.942 \\
\hline Large ( $7-10$ persons) & $8.248^{* *}$ & 3.911 \\
\hline \multicolumn{3}{|l|}{$\begin{array}{l}\text { Household education (Reference: low: below } \\
\text { high school) }\end{array}$} \\
\hline High (high school and above) & $5.095^{* * *}$ & 1.921 \\
\hline \multicolumn{3}{|c|}{ Household profession before displacement (Reference: farmer/self-employed) } \\
\hline \multicolumn{3}{|l|}{$\begin{array}{l}\text { Work unit (government agency/state } \\
\text { enterprises) }\end{array}$} \\
\hline Employed after displacement & $-5.943^{*}$ & 3.486 \\
\hline Unemployed after displacement & -2.662 & 3.033 \\
\hline \multicolumn{3}{|l|}{ Private/foreign company } \\
\hline Employed after displacement & .317 & 3.471 \\
\hline Unemployed after displacement & -5.670 & 3.862 \\
\hline No profession (full-time husband/wife) & -3.338 & 3.531 \\
\hline $\mathrm{R}^{2}$ & .207 & \\
\hline $\mathrm{N}$ & 282 & \\
\hline
\end{tabular}

${ }^{*} \mathrm{p}<0.1 ;{ }^{* *} \mathrm{p}<0.05 ;{ }^{* * *} \mathrm{p}<0.01$, S.E. $=$ Standard Error.

one hand, since the survey was conducted in an affordable housing area, there will be a concentration of low-income residents, as well as low-educated and rural households (Guo et al., 2011; Jiao, 2007). In addition, some better-off work-unit employees resort to purchasing relocated housing in the housing market rather than relying on the allocation of the affordable housing; some may have already left the area before displacement. Therefore, it is possible that only disadvantaged work-unit employees who cannot afford commercial housing, such as laidoff or retired workers, have to live there. Our respondents from work units may be composed of these remaining disadvantaged work-unit employees.

On the other hand, since work units are supported by corresponding ministries of the central government, or have to maintain good relationships with the local government (Li \& Song, 2009; Logan et al., 2010), in some demolition projects the local government coordinates with work units to make sure that employees are forced to move or to accept and sign the compensation contracts as soon as possible (so-called zhulian chaiqian, implicated demolition ${ }^{14}$ ). Otherwise, the employee could be fired, have his/her salary withheld, or have his/her political career in the work unit negatively affected (Chen, 2011; Dai \& Wang, 2004; Feng, 2007). Because the purchasing discount rate for relocated affordable housing is a negotiation condition set out in the compensation contract, in these cases, work-unit employees lose their opportunity to negotiate and are disadvantaged.

Private/foreign company employees who are unemployed following displacement have a lower discount. Although the coefficient is not significant in our model, its coefficient is high,

\footnotetext{
14 zhulian chaiqian: If one of the family members or relatives of the displaced household works in the government work unit, the local government sometimes coordinates with the work units to force the family member or relative to persuade the household to accept compensation as soon as possible. Moreover, the family member or relative must even guarantee that displaced relatives will not trouble the local government, for example with letters of complaint or visits to higher levels of government. Otherwise, the family member or relative could be fired, his/her salary could be reduced or withheld, or his/her political career in the work unit could be negatively affected.
} 
at -5.670 , which means that they received a lower discount. This is at odds with our expectations. We anticipated that they could bargain for a higher discount because their unemployment may be caused by displacement. However, the result does not support our hypothesis. These individuals may have a weak position in compensation negotiation. Although they had a source of income before displacement, they became unemployed following displacement, which means that their job is not stable. They are "middle group," which means they are not classified as low-income households whose situation will be taken into account and who would receive a higher discount from the government, nor are they as powerful in negotiation as the highly educated households, nor did they have as advantageous a pre-situation as urban villagers. This "middle" position would give them a disadvantage in the negotiation process.

\section{Conclusions}

The commodity value of land in China has become an increasingly prominent issue after a series of market-oriented reforms. Housing demolition and residential displacement induced by commercial land development have given rise to serious issues (Abramson, 1997; Wu \& He, 2005). Moreover, social conflicts have recently become more intense in China because of ruthless demolitions, insufficient compensation, and forced relocation. In some cases, members of displaced households have even set themselves on fire to fight against demolition. More households have turned to the higher authorities at the provincial and national levels for help. According to the State Bureau of Letters and Calls (state agency dealing with citizens' appeals and complaints), from 2010 onwards, among all appeals, the largest number of complaints from citizens have been associated with displacement and relocation induced by urban redevelopment and rural land acquisition ${ }^{15}$. Therefore, it is crucial to understand unequal compensation and relocation in China's current housing displacement and redevelopment problems.

In this paper we used a survey conducted among displaced residents in four affordable housing areas in Nanjing to examine uneven compensation along two dimensions: the compensation approaches and the purchasing discount of compensated affordable housing.

According to our findings, the residents who were able to obtain in-kind compensation are those who were landlords in urban villages. They had large, high-value houses before relocation. Local government attempted to use the in-kind compensation approach with a maximum limit in order to minimize the financial expenditure on compensation. Urban villages supply the housing to make up for the lack of housing for migrants in urban areas. They undertake the responsibility for housing provision for migrants, which should originally have been provided by local government at the start of urbanization. Yet urban development has brought a great deal of land interest to local revenue as well as to farmlanddeprived villagers. The local government wanted to save the land acquisition costs. In turn, they have to spend much more than ever to obtain the remaining housing plots from urban villagers. The urban villagers also received higher discount rates in purchasing their relocation affordable houses.

The findings show that those with high school education or above have strong negotiation capabilities and receive a higher discount in purchasing their affordable housing than residents with middle school education or below. It may seem surprising that

\footnotetext{
15 Source: Renminwang 2012, Chinese government official website http://theory. people.com.cn/GB/49150/18142933.html.
}

work-unit employees who are employed after displacement receive a lower discount rate. There are many explanations for this. Workunit employees may be better off, so more willing to accept low discount. Alternatively, those who live in affordable housing may have weak negotiation capacities because they are part of a disadvantaged group within the work unit who cannot afford commercial housing and have to live there, or because of local government's zhulian chaiqian (implicated demolition) policy for work-unit employees.

With the large-scale urban development and redevelopment in China's cities induced by the commercialization of housing and urban space following land and housing reform, housing inequality in terms of compensation for displacement and affordable housing allocation has become the main new inequality problem in China, especially given the large amount of affordable housing construction in recent years. Every actor involved is a rational person: local government would like to minimize compensation expenditure and maximize revenue from land leasing; displaced households will try various tactics to obtain more compensation, such as dingzi $h u$ (households who will not move out until they are awarded more compensation) or use their guanxi (social network). Inequality in displacement compensation has become universal, rather than applying to only a small number of cases.

The key to solving the problem is to establish a fair and reasonable mechanism for compensating resettlements. Specifically, local government should separate compensation from resettlement, rather than putting them together during displacement negotiations. Firstly, the amount of compensation should be determined by the market, without taking into account the situation of households, such as their income or family size. In the resettlement process, low- and middle-income displaced households who are eligible for affordable housing should be given priority to apply. Other households should enter the commercial housing market, instead of being entitled to purchase affordable housing. The fundamental reason for demolition conflicts is that local governments' fiscal revenues rely heavily on land leasing. To reduce demolition conflicts, land-based revenue should shift to the levying of a tax on property stocks, rather than relying on one-time land leasing.

\section{References}

Abramson, D. B. (1997). Marketization and institutions in Chinese inner-city redevelopment: a commentary of Lü Junhua's Beijing's old and dilapidated housing renewal. Cities, 14(2), 71-75.

Atkinson, R. (2000). The hidden costs of gentrification: displacement in central London. Journal of Housing and the Built Environment, 15(4), 307-326.

Bian, Y., \& Logan, J. R. (1996). Market transition and the persistence of power: the changing stratification system in urban China. American Sociological Review, 61(5), 739-758.

Bolt, G., \& Kempen, R. V. (2010). Dispersal patterns of households who are forced to move: desegregation by demolition: a case study of Dutch cities. Housing Studies, 25(2), 159-180.

Cartier, C. (2002). Transnational urbanism in the reform-era Chinese city: landscapes from Shenzhen. Urban Studies, 39(9), 1,513-1,532.

Chan, K. W. (1999). The hukou system and rural-urban migration in China: processes and changes. The China Quarterly, 160, 818-855.

Chen, Y. (2011). "Implicated demolition" is another administrative ruthless demolition. Urban Management, 4, 20 (in Chinese).

Dai, Y., \& Wang, T. (2004). Risk of local government's decision from the perspective of illegal displacement. Decision and Discovery, 8, 54-55 (cong "weiguichaiqian" kandifangzhengfu juecexiaoyingweiji. JuCeTanSuo).

Dowall, D. E. (1994). Urban residential redevelopment in the People's Republic of China. Urban Studies, 31(9), 1,497-1,516.

Feng, Y. (2007). A game between power, rights and interests - current legal and economic analysis of urban housing demolition. China Legal Science, 4, 39-63.

Gaubatz, P. (1999). China's urban transformation: patterns and processes of morphological change in Beijing, Shanghai and Guangzhou. Urban Studies, 36(9), 1,495-1,521.

Guo, D., Li, J., \& Wang, Z. (2011). Research on spatial distribution characteristics of indemnificatory housing in Nanjing and optimizing strategies. Modern Urban Research, 3, 83-88 (in Chinese). 
Hao, P., Sliuzas, R., \& Geertman, S. (2009). Villages within the city: housing rural migrants in the emerging mega-city of Shenzhen, China. Trialog, 102, 16-20.

Hartman, C. (1980). Displacement - a not so new problem. Habitat International, 5 , $193-202$.

He, S., \& Wu, F. (2009). China's emerging neoliberal urbanism: perspectives from urban redevelopment. Antipode, 41(2), 282-304.

Huang, Y. (2003). A room of one's own: housing consumption and residential crowding in transitional urban China. Environment and Planning A, 35 $591-614$.

Huang, Y. (2004). The road to homeownership: a longitudinal analysis of tenure transition in urban China (1949-1994). International Journal of Urban and Regional Research, 28, 774-795.

Jacobs, J. (1961). The death and life of great America cities. New York: Random House. Jiao, Y. (2007). Exploration on the mixed building mode of public housing aiming at habitation integration]. Urban Studies, 14(5), 21-28 (in Chinese).

Kempen, R. V., \& Priemus, H. (1999). Undivided cities in the Netherlands: present situation, and policy rhetoric. Housing Studies, 14(5), 641-657.

Leaf, M. (1995). Inner city redevelopment in China: Implications for the city of Beijing. Cities, 12(3), 149-162.

Lee, J., \& Zhu, Y. (2006). Urban governance, neoliberalism and housing reform in China. The Pacific Review, 19(1), 29-61.

Lin, C. S., \& Ho, P. S. (2005). The State, land system, and land development processes in contemporary China. Annals of the Association of American Geographers, 95(2), $411-436$.

Li, S., \& Song, Y. (2009). Redevelopment, displacement, housing conditions, and residential satisfaction: a study of Shanghai. Environment and Planning A, 41(5), $1,090-1,108$.

Logan, J. R., Bian, Y., \& Bian, F. (1999). Housing inequality in urban China in the 1990s. International Journal of Urban and Regional Research, 23(1), 7-25.

Logan, J. R., Fang, Y., \& Zhang, Z. (2010). The winners in China's urban housing reform. Housing Studies, 25(1), 101-117.

Nanjing Planning Bureau. Nanjing Master Planning 2007-2020. (in Chinese).

Shanghai Statistical Bureau. (2011). Shanghai statistical yearbook 2011. Shanghai: Shanghai Press. http://www.stats-sh.gov.cn/data/toTjnj.xhtml?y=2011e.

Shin, H. B. (2009). Residential redevelopment and the entrepreneurial local state: the implications of Beijing's shifting emphasis on urban redevelopment policies. Urban Studies, 46(13), 2,815-2,839.
Smith, N. (1987). Gentrification and the rent gap. Annals of the Association of American Geographers, 77, 462-465.

Wang, Y. (2000). Housing reform and its impacts on the urban poor in China Housing Studies, 15(6), 845-864.

Wang, Y., \& Murie, A. (1999). Commercial housing development in urban China. Urban Studies, 36(9), 1,475-1,568.

Wang, Y., \& Murie, A. (2000). Social and spatial implications of housing reform in China. International Journal of Urban and Regional Research, 24(2), 397-417.

Wang, Y., \& Wu, J. (2010). Housing migrant workers in rapidly urbanizing regions: a study of the Chinese model in Shenzhen. Housing Studies, 25(1), 83-100.

Wu, F. (2002). Socio-spatial differentiation in urban China: evidence from Shanghai's real estate markets. Environment and Planning A, 34(9), 1,591-1,615.

Wu, F. (2004). Intraurban residential relocation in Shanghai: modes and stratification. Environment and Planning A, 36, 7-25.

Wu, F., \& He, S. (2005). Changes in traditional urban areas and impacts of urban redevelopment: a case study of three neighbourhoods in Nanjing. China. Tijdschrift voor Economische en Sociale Geografie, 96(1), 75-95.

Yang, Y., \& Chang, C. (2007). An urban regeneration regime in China: a case study of urban redevelopment in Shanghai's Taipingqiao Area. Urban Studies, 44(9), $1,809-1,826$.

Yao, S., \& Zhu, L. (1998). Understanding income inequality in China: a multi-angle perspective. Economics of Planning, 31, 133-150.

Yuan, W., Zhu, X., \& Ma, G. (2010). A study on the features and models of residential space differentiation - A case study of Nanjing city. Human Geography, 2, 65-69 (in Chinese).

Zhang, T. (2002). Urban development and a socialist pro-growth coalition in Shanghai. Urban Affairs Review, 37(4), 475-499.

Zhang, Y., \& Fang, K. (2003). Politics of housing redevelopment in China: the rise and fall of the Ju'er Hutong Project. Journal of Housing and the Built Environment 18(1), 75-87.

Zhang, Y., \& Fang, K. (2004). Is history repeating itself? From urban renewal in the United States to inner-city redevelopment in China. Journal of Planning Education and Research, 23(3), 286-298.

Zhang, J., \& Wu, F. (2008). Mega-event marketing and urban growth coalitions: a case study of Nanjing Olympic New Town. Town Planning Review, 79, 209-226. 